\title{
Perdagangan Berjangka Komoditi : Berdzikirlah dengan Physical Delivery
}

\author{
Bambang Tutuko \\ Departemen Ekonomi Syariah \\ Universitas Internasional Semen Indonesia \\ bambang.tutuko@uisi.ac.id
}

\begin{abstract}
Commodity Futures Trading in Indonesia is administered by the government under the auspices of the Commodity Futures Trading Supervisory Agency (BAPPEBTI) with the aim of establishing the price of primary commodities (price discovery) and as a hedging facility using futures contracts. However, current futures trading is only a means of speculation caused by its specifications and transaction mechanism.

The application of the three principles of dhikr: the principle of harmony, the principle of integrity, and the principle of one on the quest for hedging solutions in commodity futures will lead to trade where the parties who transact share the risk (risk sharing). Risk sharing can only occur if there is a common goal between buyers and sellers to manage risk (the principle of the one-an). The similarity of objectives will result in a commitment between buyers and sellers to perform physical handover backed by regulation to create a liquid market (the principle of harmony), so that the wholeness of trade mechanisms involving market participants, markets, and regulators will be maintained. The integrity of the role of the stakeholders of commodity trading is what will lead to the solution of the hedge without having to separate the risk with its trading activities (principle of wholeness).

The "dhikr" hedging is a hedge accompanied by the certainty of ownership transfer through physical delivery of physical commodities. Thus, the hedge is not separate from its real trading activity, because the risk is always attached to the profit-making business activity
\end{abstract}

Keywords: Commodity Futures Trading, Hedging, Dhikr.

\section{Perdagangan Berjangka Komoditi di Indonesia.}

Perdagangan Berjangka Komoditi dibentuk dengan tujuan sebagai sarana pembentukan harga acuan komoditi primer di Indonesia dan sebagai sarana lindung nilai (hedging) bagi pelaku pasar perdagangan komoditi. Dasar berlakunya Perdagangan Berjangka Komoditi di Indonesia adalah UU No. 32/1997 sebagaimana telah diubah dengan UU No. 10 Tahun 2011 tentang Perdagangan Berjangka Komoditi. Perdagangan Berjangka Komoditi (PBK) adalah segala sesuatu yang berkaitan jual beli komoditi dengan penarikan margin dan penyelesaian kemudian berdasarkan kontrak berjangka, kontrak derivatif syariah dan atau kontrak derivatif lainnya. Pengertian Komoditi dalam undang-undang ini adalah segala sesuatu yang dapat dijadikan sebagai subyek kontrak berjangka untuk derivatif syariah dan atau kontrak derivatif lainnya diatur dengan peraturan Kepala Bappebti. Menurut sejarahnya, komoditi yang ditransaksikan diawali dari produk primer seperti produk pertanian, pertambangan, dan energy, dan kini telah mencakup berbagai produk finansial seperti Indeks Saham dan mata uang asing (Cross Currency) (www.bappebti.go.id).

Lindung nilai dengan kontrak berjangka adalah bentuk lindung nilai dalam ekonomi konvensional. Sebagian besar aktifitas lindung nilai komoditi di dunia dilakukan dengan menggunakan kontrak berjangka. Untuk dapat melakukan perbandingan antara lindung nilai secara konvensional dengan lindung nilai Islam, maka perlu untuk dijelaskan bagaimana mekanisme lindung nilai dengan menggunakan kontrak berjangka ini.

Kontrak berjangka (futures) adalah suatu perjanjian yang mewajibkan kedua belah pihak yang melakukan transaksi, yaitu untuk membeli (long position) atau menjual (short position) suatu aset dasar (underlying asset) tertentu yang penyerahannya (delivery) dilakukan di waktu yang akan datang dengan harga yang telah ditetapkan pada saat kontrak dilakukan (Hull, 2008). 
Transaksi kontrak berjangka ini pada awal perkembangannya digunakan dalam perdagangan komoditi yaitu untuk menjual suatu komoditi, misalnya komoditi pertanian, dari hasil panen di masa yang akan datang dengan harga yang ditetapkan sekarang. Berbeda dengan kontrak forward, kontrak futures adalah suatu kontrak terstandarisasi antara dua pihak, melibatkan ketentuan-ketentuan terstandarisasi, dalam hal jumlah dan tanggal penyerahan barang, diperdagangkan dalam suatu Bursa Berjangka (Exchange) seperti New York Merchantile Exchange, Bursa Berjangka Jakarta, dikuotasikan sesuai dengan harga pasar harian, dan harus memenuhi persyaratan-persyaratan marjin periodik. Penyelesaian perdagangan kontrak Futures dapat dilakukan dengan cara serah-terima fisik (physical delivery) di akhir kontrak, atau dengan cara off-set dengan pembayaran tunai (cash settlement) pada saat kontrak berjalan.

Perbedaannya dengan kontrak forward, dalam kontrak futures harga tidak ditentukan. Pada kontrak futures, harga yang digunakan adalah harga pasar pada tanggal yang disepakati. Kontrak berjangka (futures) dapat berupa komoditi seperti bahan makanan ataupun komoditi industri, yang disebut dengan futures komoditi (commodity futures). Adapun kontrak futures yang underlying asset-nya adalah instrumen keuangan disebut dengan futures keuangan (financial futures).

Kontrak futures dan kontrak forward merupakan suatu perjanjian untuk menjual atau membeli suatu jumlah aset tertentu, umumnya adalah komoditi atau instrumen keuangan, dengan tingkat harga tertentu yang ditentukan sekarang untuk dilaksanakan pada suatu saat di masa yang akan datang. Perbedaannya adalah futures hanya diperdagangkan di bursa yang diatur oleh suatu otoritas, karenanya ketentuan-ketentuan futures tersebut adalah baku (standard terms). Sedangkan forward diperdagangkan di luar bursa, atau secara popular disebut over-the-counter (OTC). Karenanya ketentuan-ketentuan forward tersebut adalah hasil negosiasi para pihak yang bertransaksi (negotiated terms). Futures juga umumnya hanya atas benda berwujud (tangible assets) dan penyelesaian transaksi dilakukan melalui penyerahan secara fisik (physical delivery), kecuali futures yang aset dasarnya adalah indeks, dimana penyelesaiannya dilakukan melalui pembayaran tunai (cash settlement). Semua pembeli dan penjual dari kontrak futures diwajibkan untuk membuka akun/rekening dan memasukkan serta memelihara suatu margin deposit yang sebenarnya ditentukan oleh bursa (Hull, 2008).

\section{Lindung Nilai (Hedging) dengan Perdagangan Berjangka Komoditi.}

Kontrak berjangka (futures) oleh para produsen dijadikan sebagai sarana untuk melakukan lindung nilai (hedging), yaitu strategi untuk mengurangi resiko yang diakibatkan oleh fluktuasi harga. Sedangkan dalam perkembangan selanjutnya, margin trading dalam perdagangan berjangka membuat para spekulan melihat bahwa kontrak ini sangat menarik untuk dikembangkan menjadi instrumen untuk spekulasi. Seorang spekulan dapat saja membeli kontrak futures untuk penyerahan barang di masa yang akan datang, dan mulai berspekulasi dengan perkiraan harga komoditi pada saat penyerahan. Dalam hal ini, para spekulan mengambil alih resiko dari para produsen/petani. Sejak saat itulah terjadinya pasar berjangka sebagai sarana spekulasi.

Dalam setiap kegiatan perdagangan, pengusaha selalu mengharapkan keuntungan, akan tetapi juga dihadapkan kepada resiko kerugian yang selalu melekat dalam kegiatan usahanya. Resiko umumnya berasal dari akibat perubahan harga barang, perubahan kurs mata uang, suku bunga, inflasi dan lain sebagainya. Untuk melindungi pengusaha dari resiko tersebut dapat dilakukan melalui lindung nilai (hedging) dengan kontrak futures di Bursa Berjangka. Dengan melakukan lindung nilai, resiko tersebut dapat dialihkan (transfer of risk) kepada investor yang mengharapkan keuntungan dari perubahan harga di Bursa Berjangka.

Lindung nilai adalah suatu kegiatan pengambilan posisi di pasar berjangka yang berlawanan dengan posisinya di pasar fisik. Dengan mengambil posisi yang berlawanan antara pasar berjangka dan pasar fisik, maka kerugian yang timbul akibat adanya fluktuasi harga di pasar fisik dapat dikurangi dengan keuntungan yang diperoleh di pasar berjangka, atau sebaliknya (Umar, 2001:272).

Lindung nilai dengan menggunakan kontrak berjangka adalah lindung nilai yang dilakukan dengan cara mengalihkan resiko salah satu pihak kepada pihak lainnya, karena kontrak berjangka diperdagangkan dengan sistem zero-sum. Oleh karena itu, lindung nilai dengan menggunakan kontrak berjangka dikategorikan sebagai aktifitas transfer resiko (risk transfer). Dalam Islam, mitigasi resiko 
seharusnya dilakukan dengan cara mengelola resiko bersama atau risk sharing, dimana dalam hal ini pihak pembeli dan penjual akan menanggung dan mengelola resiko secara bersama-sama dan tidak ada pihak yang lebih dirugikan karena harus menanggung resiko dari pihak yang lain. Risk transfer akan menimbulkan win-lose situation, sedangkan risk sharing akan menimbulkan win-win situation. Karena risk transfer bisa menimbulkan win-lose situation dimana ada pihak yang akan dirugikan, maka hal ini membuka kesempatan bagi pihak penanggung resiko untuk melakukan upaya-upaya apapun agar tidak rugi, termasuk di dalamnya adalah menghalalkan segala cara.

Risk transfer dengan menggunakan kontrak berjangka mengandung sebuah pengertian bahwa kedua belah pihak, baik pembeli maupun penjual, saling membebankan resiko yang timbul dari fluktuasi harga komoditi. Apabila timbul resiko pada pembeli, maka pihak penjual lah yang harus menanggung resikonya, dan begitu pula sebaliknya. Oleh karena itu, kontrak berjangka dibuat dengan spesifikasi yang memungkinkan pihak-pihak yang bertransaksi untuk melikuidasi posisinya setiap saat dan pada harga berapa pun tanpa harus melibatkan proses serah-terima fisik komoditi yang bersangkutan. Sehingga, pihak pembeli yang awalnya ingin mendapatkan barang, begitu juga pihak penjual yang awalnya ingin menjual barangnya, pada akhirnya terekspos pada sebuah situasi ketidakpastian akan harga serta proses serah-terima fisik komoditi. Situasi ini tidak sesuai dengan prinsip Islam, sebagaimana firman Allah SWT dalam QS. An-Nisa:29 :

"Hai orang-orang yang beriman, janganlah kamu saling memakan harta sesamamu dengan jalan yang batil, kecuali dengan jalan perniagaan yang berlaku dengan suka sama-suka di antara kamu. dan janganlah kamu membunuh dirimu; Sesungguhnya Allah adalah Maha Penyayang kepadamu."

Menurut QS. An-Nisa:29, lindung nilai (hedging) seharusnya dilakukan dengan prinsip saling menguntungkan (suka-sama-suka) antara pihak pembeli dan penjual. Bila mekanisme lindung nilai yang dilakukan masih bisa merugikan salah satu pihak, maka mekanisme tersebut tidak dapat disebut sebagai mekanisme lindung nilai yang Islami.

Kontrak berjangka (futures) juga diperdagangkan dengan menggunakan uang jaminan (margin), sehingga memberi kesempatan kepada pelaku pasar untuk melakukan penjualan kontrak berjangka tanpa harus memiliki komoditinya terlebih dahulu (short selling). Hal ini melanggar prinsip jual-beli dalam Islam dimana seseorang boleh menjual barangnya hanya jika telah menerima dari pihak penjual dan menguasainya, sebagaimana hadits berikut ini :

"Dari Abdullah bin Umar Radhiyallahu anhuma, bahwa Rasulullah SAW bersabda, 'Barangsiapa membeli bahan makanan, maka janganlah dia menjualnya kembali sebelum menerimanya.” (HR. AlBukhari dan Muslim)

Syarat untuk bisa menjual komoditi hanya jika telah menerima dari penjual dan menguasainya bertujuan untuk menghindari praktik-praktik yang mengarah kepada judi (maysir). Kontrak berjangka yang diperdagangkan dengan menggunakan uang jaminan (margin) menjadikan instrumen tersebut lebih banyak digunakan sebagai sarana berspekulasi untuk mendapatkan keuntungan dari pergerakan harganya. Hal ini disebabkan karena berdagang dengan menggunakan uang jaminan memberikan faktor kelipatan tinggi (high leverage) bagi pembeli dan penjual untuk mendapatkan keuntungan yang jauh lebih tinggi bila dibandingkan dengan berdagang fisik komoditi. Adanya high leverage inilah yang menyebabkan terjadinya praktik spekulasi dengan menggunakan kontrak berjangka. Allah SWT mengharamkan praktik spekulasi yang berlebihan karena identik dengan judi (maysir), sebagaimana firmanNya dalam QS. AlMaidah:90 :

"Hai orang-orang yang beriman, sesungguhnya (meminum) khamar, berjudi, (berkorban untuk) berhala, mengundi nasib dengan panah, adalah termasuk perbuatan syaitan. Maka jauhilah perbuatanperbuatan itu agar kamu mendapat keberuntungan." 


\section{Metodologi Penelitian dengan Dzikrullah Analysis.}

Penelitian ini dilakukan secara kualitatatif dengan menggunakan paradigma posmoderen dimana mengganggap bahwa realitas bersifat relatif tergantung dari sudut pandang peneliti dalam menganalisis. Ciri yang khas dari penelitian posmoderen adalah pengangkatan kembali yang telah terpinggirkan dengan cara memasukkan hal-hal yang telah diabaikan dalam mainstream diskursus (Kamayanti, 2016). Posmodernitas dalam penelitian ini adalah pengangkatan kembali konsep dzikir dan memasukkannya ke dalam praktik lindung nilai (hedging) sehingga bisa memunculkan konsep dzikrullah hedging, yaitu lindung nilai yang "berdzikir".

Penggalian data penelitian ini dilakukan melalui tiga cara, yaitu : in-depth interview, studi kepustakaan, dan dokumentasi. In-depth interview dengan key informant yang merupakan praktisi perdagangan berjangka komoditi ditujukan untuk menggali dinamika praktik perdagangan berjangka komoditi. Studi kepustakaan meliputi dalil-dalil dalam Al-Qur'an dan As-Sunnah, serta penelitian terdahulu. Sedangkan yang dimaksud dengan dokumentasi adalah segala data yang tertulis, tercetak, dan terekam yang dapat digunakan sebagai sumber informasi tentang konsep dan mekanisme lindung nilai Islam.

Penelitian ini dimulai dengan menggali prinsip-prinsip dzikir dari Al-Qur'an dan As-Sunnah agar dapat digunakan sebagai alat untuk menganalisis praktik perdagangan berjangka komoditi. Analisis dengan menggunakan prinsip dzikir ini dilakukan dengan cara triangulasi antara : hasil in-depth interview, penelitian terdahulu, dan dokumentasi, sehingga menghasilkan sebuah solusi menuju perdagangan berjangka yang "berdzikir".

\section{Tiga Prinsip Dzikir.}

Lindung nilai (hedging) sangat dibutuhkan oleh pelaku pasar perdagangan komoditi pertanian di Indonesia sebagai sarana mitigasi resiko akibat fluktuasi harga. Harga komoditi yang berfluktuasi menyebabkan ketidakpastian baik bagi pihak pembeli maupun penjual komoditi. Pihak pembeli yang membutuhkan komoditi melakukan lindung nilai untuk memitigasi resiko akibat kenaikan harga beli, demikian pula pihak penjual melakukan lindung nilai untuk memitigasi resiko akibat penurunan harga jual komoditi. Lindung nilai adalah salah satu bentuk manajemen resiko keuangan.

Dalam kaitannya dengan manajemen resiko, Islam mengajarkan untuk mempersiapkan hari esok dengan sebaik-baiknya, termasuk di dalamnya adalah mempersiapkan cara untuk mengelola resiko keuangan yang bisa timbul di hari esok, sebagaimana firman Allah SWT dalam QS. Al-Hasyr:18-19 :

"Hai orang-orang yang beriman, bertakwalah kepada Allah dan hendaklah Setiap diri memperhatikan apa yang telah dikedepankannya untuk hari esok (akhirat); dan bertakwalah kepada Allah, Sesungguhnya Allah Maha mengetahui apa yang kamu kerjakan.”

\section{"Dan janganlah seperti orang-orang yang lupa kepada Allah, lalu menjadikan mereka lupa kepada diri} mereka sendiri. Mereka itu adalah orang-orang yang fasik"

Menurut Tafsir Al-Misbah, kata "tuqaddimu/dikedepankan" di ayat 18 digunakan dalam arti amal-amal yang dilakukan untuk meraih manfaat di masa yang akan datang. Ini seperti seorang tukang kayu yang telah menyelesaikan pekerjaannya. Ia dituntut untuk memerhatikannya kembali agar menyempurnakannya bila telah baik, atau memperbaikinya bila masih ada kekurangannya, sehingga jika tiba saatnya diperiksa, tidak ada lagi kekurangan dan barang tersebut tampil sempurna. Akan tetapi, dijelaskan di ayat 19 bahwa orang-orang yang lupa untuk mempersiapkan diri untuk hari esok sebenarnya adalah orang-orang yang lupa kepada Allah. Dengan kata lain, akibat sikap lupa itu Allah menjadikan mereka lupa kepada diri mereka sendiri sehingga mereka tidak melakukan sesuatu yang bermanfaat bagi diri mereka untuk mendapat keberuntungan (Shihab, 2002:552-553). Tafsir ini menjelaskan bahwa persiapan diri untuk hari esok adalah perintah takwa dan berfokus pada evaluasi diri terhadap amalan yang telah atau sedang dilakukannya. Semakin baik evaluasi yang dilakukannya, semakin besar pula manfaat yang akan didapatkannya di masa yang akan datang. Jadi, evaluasi diri adalah sebuah persiapan 
untuk hari esok. Akan tetapi, kemampuan untuk melakukannya adalah pemberian dari Allah akibat selalu ingat kepadaNya. Kemampuan dan kesempatan untuk evaluasi diri hanya sebuah akibat, penyebab utamanya adalah selalu ingat kepada Allah (dzikrullah).

Yang dimaksud "hari esok" di ayat 18 tersebut tidak hanya urusan akhirat, melainkan segala kemungkinan yang bisa terjadi di masa yang akan datang yaitu munculnya resiko keuangan. Manusia diperintah oleh Allah SWT untuk mempersiapkan diri dengan baik agar bisa meminimalkan dampak negatif dari terjadinya resiko di masa yang akan datang. Dampak negatif dari resiko itu adalah kerugian yang akhirnya bisa membawa manusia kepada kebangkrutan dan kemiskinan. Salah satu bentuk upaya untuk memitigasi resiko tersebut adalah melakukan lindung nilai. Dan lindung nilai yang baik menurut Islam adalah lindung nilai yang bermakna "ingat kepada Allah".

\section{Prinsip Keserasian (Principle of Harmony) dalam Tasbih.}

Salah satu bentuk dzikir adalah menyucikan Allah (tasbih). Pada kenyataannya, seluruh alam semesta dan seisinya senantiasa berdzikir dengan bertasbih, sebagaimana firmanNya berikut ini :

"Langit yang tujuh, bumi dan semua yang ada di dalamnya bertasbih kepada Allah. Dan tak ada suatu pun melainkan bertasbih dengan memujiNya, tetapi kamu sekalian tidak mengerti tasbih mereka. Sesungguhnya Dia adalah Maha Penyantun lagi Maha Pengampun.”(QS. Al-Isra:44)

"Tidakkah kamu tahu bahwasanya Allah, kepadaNya bertasbih apa yang di langit dan di bumi dan (juga) burung dengan mengembangkan sayapnya. Masing-masing telah mengetahui (cara) sembahyang dan tasbihnya, dan Allah Maha Mengetahui apa yang mereka kerjakan." (QS. An-Nur:41)

Tasbih langit dan bumi dipahami oleh sementara ulama dalam arti majazi, yakni dalam arti kepatuhannya mengikuti hukum-hukum Allah yang berlaku atasnya. Atau, keadaan setiap ciptaan Allah yang demikian sempurna dan serasi, bukan saja pada wujudnya atau sistem kerjanya sebagai satu kesatuan, tetapi juga dalam bagian dan perincian masing-masing satuan. Keserasian itulah tasbihnya (Shihab, 2002:103).

Tasbih adalah penyucian dengan ucapan atau kalam, sedangkan hakikat kalam adalah mengungkap apa yang terdapat dalam benak dengan cara tertentu. Manusia menggunakan lafadz-lafadz tertentu yang merupakan suara yang disepakati maknanya untuk mengungkap apa yang ingin disampaikannya, dan boleh jadi juga menggunakan isyarat tangan, kepala, atau selain keduanya dari anggota badannya atau menggunakan tulisan atau menetapkan tanda untuk tujuan mengungkap maksud hati itu, bahkan mengkhususkan penyebutan burung karena uniknya keadaan burung-burung saat terbang mengembangkan sayapnya, dan semuanya membuktikan keesaan Allah. (Shihab, 2002:574-575).

Kedua ayat tersebut menjelaskan bahwa semua ciptaan Allah berdzikir dengan bertasbih kepadaNya dengan cara mereka masing-masing. Bila burung saja bertasbih dengan mengepakkan sayapnya sebagai kalam-nya, maka manusia pun tentunya bertasbih baik dengan ucapan maupun kalam yang berupa isyarat, tindakan, termasuk pula aktifitas muamalah. Lindung nilai adalah salah satu aktifitas muamalah yang menjadi sarana bagi manusia untuk berdzikir dengan bertasbih kepadaNya. Manusia yang berdzikir dan bertasbih akan tercermin dalam aktifitas kesehariannya, apabila sedang bermuamalah maka muamalahnya akan mengandung nilai-nilai $d z i k r u l l a h$. Muamalah yang bertasbih adalah muamalah yang senantiasa menjaga keserasian di dalam prosesnya. Keserasian memiliki arti yang meliputi keseimbangan, kesatuan, keselarasan, serta konsistensi. Tasbih memunculkan prinsip keserasian (priciple of harmony) dalam muamalah, termasuk di dalamnya adalah lindung nilai.

Dzikir yang berkualitas adalah dzikir yang menjaga keserasian secara menyeluruh dalam prosesnya. Allah SWT berfirman dalam QS. Al-Baqarah:152 :

"Karena itu, ingatlah (dzikir) kepadaKu niscaya Aku ingat (pula) kepada kamu, dan bersyukurlah kepadaKu, dan janganlah kamu mengingkari (nikmat)-Ku." 
Ayat tersebut menjelaskan begitu besarnya limpahan karunia Allah, karena itulah Allah memerintahkan kita untuk senantiasa ingat (berdzikir) kepadaNya dengan lidah, pikiran hati, dan anggota badan, dimana lidah menyucikan dan memujiNya, pikiran dan hati memerhatikan tanda-tanda kebesaranNya, dan anggota badan melaksanakan perintah-perintahNya. Jika itu semua dilakukan niscaya Allah akan ingat pula kepada kita, sehingga Allah akan bersama kita saat suka maupun duka. Kemudian bersyukurlah kepadaNya dengan hati, lidah, dan perbuatan, niscaya akan Allah tambah nikmat-nikmatNya, dan janganlah kita ingkari nikmatNya agar siksaNya tidak menimpa kita (Shihab, 2002:433).

QS. Al-Baqarah ayat 152 ini menjelaskan bahwa "ingat kepada Allah" harus dilakukan secara menyeluruh (kaffah) meliputi lisan, pikiran dan hati, serta tindakan, dimana lisan adalah hulunya dan tindakan sebagai hilirnya. Keserasian "hulu ke hilir" inilah yang menentukan kualitas dzikrullah (ingat kepada Allah) sehingga akan membuat Allah ingat pula kepada kita dengan memberikan solusi dari setiap permasalahan. Ketidakserasian antara hulu dan hilir akan menimbulkan permasalahan, dimana solusinya tidak bisa diperoleh hanya berfokus pada hulu atau hilir saja, tetapi harus menyeluruh mulai dari hulu hingga ke hilir sebagai suatu kesatuan. Keserasian dari hulu ke hilir, dari lisan yang menggerakkan pikiran dan hati sehingga menimbulkan tindakan, adalah hakikat kesempurnaan dzikrullah.

Konsep keserasian hulu ke hilir ini terbukti dalam penerapan rantai pasok halal (halal supply chain) dimana prosesnya dimulai dari sumber pasokan (source of supply) sampai dengan barang tersebut sampai kepada konsumen. Bila hal ini menyangkut produk daging halal maka yang dimaksud dengan halal supply chain adalah keseluruhan proses mulai dari cara beternak (farming), pemberian dan jenis makanan (animal feeding), cara penyembelihan (proper slaughtering), pengiriman (transporting) dan penyimpanan (storing) hingga produk tersebut sampai kepada konsumen sesuai dengan syariah Islam. Pada intinya adalah bagaimana meyakinkan bahwa konsep halal ini tidak hanya diterapkan pada produk atau makanan saja, tetapi juga pada seluruh aktifitas di dalam rantai pasok produk tersebut termasuk manajemen persediaan dan penanganan material (Omar, Emi N. and Jaafar, Harlina S., 2011; Lindgren, A. and Hingley, M., 2003; Folinas, D., Manikas, I. and Manos, B., 2006; Suhaiza, Z. et al, 2009; Petracci, M., Bianchi, M., Cavani, C., 2010; Talib, Z., Zailani, S., and Zainuddin, Y., 2010). Setiap langkah dan fase dalam rantai pasok halal berperan penting untuk mengidentifikasi critical halal control point dimana bisa menyebabkan produk halal menjadi produk non-halal akibat kontaminasi dan pencampuran dengan produk non-halal saat proses penanganan, penyimpanan, pengemasan, dan pengiriman. Dengan dasar pemikiran yang sama, terjadinya sebuah permasalahan pada praktik lindung nilai sebenarnya disebabkan oleh ketidakserasian dari hulu ke hilirnya, sehingga pada kondisi yang demikian bisa dikatakan bahwa praktik lindung nilainya "belum berdzikir" kepada Allah. Lindung nilai yang "berdzikir" adalah lindung nilai yang seharusnya meliputi bagaimana sebuah barang/komoditi diproduksi, dibiayai, hingga akhirnya barang/komoditi tersebut bisa dijual. Aktifitas lindung nilainya terletak pada bagaimana menyerasikan antara produksi yang berkualitas, pembiayaan yang syariah, hingga kepastian penjualan komoditi.

Akad salam adalah acuan mekanisme lindung nilai yang Islami untuk perdagangan komoditi pertanian di Indonesia. Sektor pertanian dan perkebunan di Indonesia sebagai negara agraris merupakan pangsa pasar yang besar bagi lembaga keuangan syariah untuk menyalurkan pembiayaan dengan menggunakan akad salam. Akan tetapi, masih terdapat beberapa permasalahan terkait dengan penerapan akad salam sehingga sampai dengan saat ini belum juga dapat terealisasi. Permasalahan utama pada penerapan pembiayaan salam tersebut disebabkan oleh tingginya resiko bagi pihak bank akibat kredibilitas keuangan petani dan faktor alam yang sangat memengaruhi hasil panen (Ningsih, 2015; Adnan, Revisa, dan Faiq, 2016). Sebenarnya penyebab utama timbulnya resiko tersebut adalah perbedaan pemikiran antara bank syariah dan petani, dimana pembiayaan salam berlogika uang sedangkan petani berlogika mekanisme alam. Logika mekanisme alam ini sesuai dengan persepektif dari petani itu sendiri yang mana pembiayaan akad salam dianggap sebagai pembiayaan musiman yang harus menyesuaikan dengan faktor alam. Faktor alam seperti cuaca yang tidak bisa diperkirakan dan juga bencana alam yang tidak bisa diprediksi merupakan suatu penghambat dalam kegiatan usaha taninya sehingga berdampak juga terhadap pendapatan yang diperoleh oleh petani apabila usaha taninya mengalami gagal panen. Pada akhirnya petani yang menggunakan pembiayaan salam tidak dapat melunasi pembayaran kepada bank saat jatuh tempo pembayaran yang senantiasa menggunakan periode bulanan (Affandi, 2014). Perbedaan 
paradigma antara bank syariah dan petani yang berujung masalah ini adalah sebuah bukti tidak berjalannya prinsip keserasian (principle of harmony) yang digali dari dzikir tasbih, sehingga solusinya adalah bagaimana mewujudkan keserasian antara bank syariah dengan petani agar akad salam ini dapat diterapkan sebagai sarana lindung nilai.

\section{Prinsip Keutuhan (Principle of Integrity) dalam Tahmid.}

Lafadz dzikir yang berikutnya adalah tahmid, yaitu alhamdulillah, yang bermakna memuji Allah. Allah SWT berfirman dalam QS. Al-Fatihah:2 :

\section{"Segala puji bagi Allah pemelihara seluruh alam."}

Kata al-hamd terdiri dari dua huruf alif dan lam (baca $A l$ ) bersama dengan hamd. Dua huruf alif dan lam yang menghiasi kata hamd oleh para pakar bahasa dinamai al-istighraq dalam arti mencakup segala sesuatu. Itu sebabnya alhamdulillah seringkali diterjemahkan dengan segala puji bagi Allah. Pada kata alhamdulillah, huruf lam yang menyertai kata Allah mengandung makna pengkhususan bagiNya. Ini berarti bahwa segala pujian hanya wajar dipersembahkan kepada Allah SWT. Dia dipuji karena Dia yang menciptakan segala sesuatu dan segalanya diciptakanNya dengan "baik", penuh kesadaran, dan tanpa paksaan. Dengan alhamdulillah, si pengucap menyimpulkan bahwa segala sesuatu yang bersumber dari Allah adalah terpuji, walau suatu kondisi atau ketetapan itu tidak sejalan dengan kepentingan si pengucap atau dia duga merugikannya. Dugaan merugikan, atau penilaian negatif itu, pada hakikatnya lahir dari keterbatasan pandangan manusia. Pasti ada sesuatu yang luput dari jangkauan pandangannya sehingga penilaiannya menjadi demikian.

Lanjutan ayat ini menyatakan bahwa Allah Rabb al-'alamin. Kata rabb, seakar dengan kata tarbiyah, yaitu mengarahkan sesuatu tahap demi tahap menuju kesempurnaan kejadian dan fungsinya. Ketika menyebut kata rabb, dalam kandungan makna kata ini terhimpun semua sifat-sifat Allah yang dapat menyentuh mahluk. Pengertian rububiyah (kependidikan atau pemeliharaan) mencakup pemberian rejeki, pengampunan dan kasih sayang, juga amarah, ancaman, siksaan, dan sebagainya. Ini berarti bahwa ketetapanNya yang terlihat oleh kacamata manusia sebagai negatif, pada dasarnya tidak terlepas dari pemeliharaan dan pendidikanNya. Sarana pendidikan dan pemeliharaan Allah terhadap manusia disiapkanNya jauh sebelum manusia wujud di bumi ini, bumi dengan segala kesempurnaan dan kecukupannya bagi manusia, bahkan surga yang akan dihuninya kelak pun telah disiapkan olehNya. Semua nikmat telah Dia wujudkan sebelum kewajiban mensyukuri dan bahkan sebelum yang harus bersyukur hadir di pentas kehidupan (Shihab, 2002:32-37).

Memuji Allah SWT adalah luapan rasa syukur yang memenuhi jiwa seorang mukmin dikala mendengar namaNya disebut. Hal ini disebabkan karena keberadaan seseorang sejak semula di pentas bumi ini tidak lain kecuali limpahan nikmat Ilahi yang mengundang rasa syukur dan pujian. Setiap kejapan, setiap saat, dan pada setiap langkah, silih berganti anugerah Allah berduyun-duyun, lalu menyatu dan tercurah kepada seluruh mahluk, khususnya manusia. Karena itu, adalah wajar memulai dengan memujiNya dan mengakhiri pun dengan memujiNya. "Dia Allah. Tiada Tuhan selain Dia. Bagi-Nya saja segala puji sejak awal (dalam kehidupan dunia ini) dan di akhirat nanti.” (QS. Al-Qashash:70).

Segala sesuatu yang terjadi di muka bumi ini adalah ketetapanNya, semuanya penuh dengan kebaikan, dan oleh karenanya kita harus memujiNya. Fluktuasi harga komoditi pertanian yang dipandang oleh manusia sebagai sesuatu yang negatif karena mengandung resiko sebenarnya adalah sesuatu yang baik dan tidak terlepas dari pemeliharaanNya, sehingga solusinya pun sudah menyatu dengan kejadiannya. "Karena sesungguhnya sesudah kesulitan itu ada kemudahan, sesungguhnya sesudah kesulitan itu ada kemudahan." begitu firman Allah dalam QS. Al-Insyirah ayat 5-6. Kesadaran bahwa segala kejadian adalah sesuatu yang baik akan menimbulkan sikap bersyukur bahwa setiap kejadian yang dianggap sebagai masalah ternyata utuh dan lengkap dengan solusinya, dimana solusinya bisa berupa sebuah instrumen, mekanisme, atau apa saja yang masih terkait dan tidak terpisahkan dengan 
kejadiannya. Pemikiran bahwa "solusi ada di dalam masalahnya" timbul dari sebuah prinsip bahwa semua kejadian adalah utuh (principle of integrity) sehingga akhirnya terucap kalimat pujian kepadaNya, alhamdulillahirabbil'alamiin.

Prinsip keutuhan ini sangat terkait dengan prinsip keserasian (principle of harmony) yang digali dari tasbih. Segala sesuatu yang serasi secara kaffah, dari hulu ke hilir, tentunya terjaga keutuhannya, dengan kata lain unsur-unsur penyusunnya tak terpisahkan. Permasalahan dalam sebuah aktifitas muamalah seringkali disebabkan karena adanya upaya "pemisahan" antara unsur-unsur penyusunnya, sehingga mengganggu keserasiannya. Perbedaan konsep risk sharing dan risk transfer dalam manajemen resiko bisa diambil sebagai contoh.

Konsep risk sharing dalam manajemen resiko Islam adalah salah satu hasil dari pemikiran dengan menggunakan prinsip keutuhan (principle of integrity) dimana setiap kejadian adalah utuh sehingga setiap permasalahan diciptakan oleh Allah tak terpisahkan dengan solusinya. Konsep risk sharing ini menolak konsep pemindahan resiko (risk transfer) sebagai metode mitigasi resiko dalam manajemen resiko konvensional. Memindahkan resiko kepada pihak lain menunjukkan adanya langkah untuk menghindari resiko (risk aversion) yang merupakan pemisahan antara resiko dengan kegiatan bisnisnya. Hal ini tidak sesuai dengan prinsip Islam : al-kharaj bi al-daman dan al-ghunm bi al-ghurm. Prinsip al-kharaj bi aldaman adalah prinsip berdasarkan hadits riwayat Ibnu Majah dalam Kitab Al-Tijarat, Bab Al-Kharaj bi Al-Daman, hadits nomer 2243, yang menyatakan bahwa keuntungan (profit) bisa didapatkan karena keberanian seseorang mengambil resiko, sehingga bila tidak mau mengambil resiko maka jangan mengharapkan keuntungan (no risk no gain). Semua keuntungan yang didapatkan tanpa mengelola resiko termasuk dalam kategori riba (Chapra, 2008). Demikian pula prinsip al-ghunm bi al-ghurm dimana seseorang layak mendapatkan keuntungan hanya apabila dia bersedia untuk menghadapi kemungkinan untuk rugi, returns are justified by taking risks (Ayub, 2007). Dari realitas ini bisa ditarik kesimpulan bahwa keuntungan tidak bisa dipisahkan dari resikonya, dengan kata lain resiko terkait dengan aktifitas bisnisnya. Solusi untuk resiko tersebut adalah dengan cara mengambil dan mengelola resiko itu sendiri, bukan menghindari dan memindahkan resiko. Lindung nilai yang sesuai dengan prinsip Islam adalah lindung nilai yang bertujuan untuk mengurangi resiko (risk reduction) dengan cara risk sharing, bukan memindahkan resiko kepada lawan transaksi sehingga membuka kesempatan untuk berspekulasi (Ahmad and Halim, 2014). Hal ini sejalan dengan prinsip keutuhan (principle of integrity) dimana semua kejadian adalah utuh sehingga setiap solusi pasti melekat di setiap permasalahan, solusi untuk mengelola resiko bisnis terdapat pada keutuhan aktifitas bisnis itu sendiri.

\section{Prinsip Ke-Satu-an (Principle of One) dalam Tahlil dan Takbir.}

Bentuk dzikir yang berikutnya adalah tahlil, laa ilaaha ilallaah, dan takbir, Allahu Akbar. Menjadikan satu pembahasan tentang tahlil dan takbir ini karena keduanya sama-sama menjelaskan tentang kesempurnaan Zat Allah, sebagaimana firmanNya berikut ini :

"Dia Allah Yang tiada Tuhan selain Dia, Maha Mengetahui yang gaib dan yang nyata, Dialah arRahman lagi ar-Rahim." (QS. Al-Hasyr:22)

Al-Biqa'i berkomentar tentang kata huwa pada QS. Al-Hasyr ayat 22 di atas bahwa Dia yang wujudNya dari zatNya sendiri sehingga Dia sama sekali tidak disentuh oleh 'adam (ketiadaan) dalam bentuk apapun, dan dengan demikian tidak ada wujud yang pantas disifati dengan kata tersebut selainNya karena Dialah yang selalu wujud sejak dahulu hingga kemudian yang tidak terhingga (Shihab, 2002:558).

"Dan katakanlah: "Segala puji bagi Allah yang tidak mempunyai anak dan tidak mempunyai sekutu dalam kerajaanNya dan Dia bukan pula hina yang memerlukan penolong dan agungkanlah Dia dengan pengagungan yang sebesar-besarnya." (QS. Al-Israa':111)

Kata kabbirhu yang berarti "agungkanlah Dia" dalam QS. Al-Israa' ayat 111 mencakup pengagungan dengan hati, lidah, dan perbuatan. Sementara ulama berpendapat bahwa kandungan makna kata tersebut 
jika yang dimaksud dengannya sifat Allah adalah keagungan dan kekuasaan. Imam Ghazali memahaminya dalam arti kesempurnaan Zat, yang juga berarti kesempurnaan wujudNya, dimana kesempurnaan wujud ditandai oleh dua hal, yaitu keabadian dan sumber wujud. Allah kekal abadi, Dia awal yang tanpa permulaan dan akhir yang tanpa pengakhiran. Tidak dapat tergambar dalam benak , apalagi dalam kenyataan, bahwa Dia pernah tiada dan suatu ketika akan tiada. Allah adalah Zat yang wajib wujudNya. Berbeda dengan mahluk yang wujudnya didahului oleh ketiadaan dan diakhiri pula oleh ketiadaan. Dari segi sumber wujud, Dia adalah sumbernya karena setiap yang maujud pasti ada yang mewujudkannya. Mustahil sesuatu dapat mewujudkan dirinya sebagaimana mustahil pula ketiadaan yang mewujudkannya. Jika demikian, benak kita pasti berhenti pada wujud yang wajib dan yang merupakan sumber dari segala yang wujud. Dialah Allah Yang Maha Besar (Shihab, 2002:218).

Memikirkan tentang kesempurnaan wujudNya yang tidak berawal dan tidak berakhir, tidak diawali dengan ketiadaan dan tidak diakhiri oleh ketiadaan, akan mengarahkan pada kesadaran bahwa semua kejadian di alam semesta ini disebabkan oleh sumber dari segala sumber sebab, yaitu Sang Satu (Ahad), Allah SWT. Segala keberagaman ciptaanNya, yaitu alam semesta dan seluruh kejadian di dalamnya sebenarnya mengandung sebuah kesamaan yang hakiki, yaitu sama-sama bersumber dari Sang Ahad, merefleksikan wujud Yang Tunggal, yaitu Allah. Hukum yang tersebar di alam ini adalah hukum keberagaman yang terikat dalam satu kesatuan (Triyuwono, 2015:387). Bila demikian, perbedaan itu sendiri adalah sebuah kesamaan, yaitu sama-sama dibuat berbeda dan unik. Keunikan dalam keberagaman ciptaanNya menunjukkan kebesaranNya. Segala sesuatu yang unik berarti tidak sama dengan lainnya, bahkan bisa dikatakan segala sesuatu diciptakan hanya ada "satu" di alam semesta ini, dimana merupakan perwujudan sifatNya yang Ahad. Manusia yang satu tidak sama dengan manusia yang lain, bahkan pada saudara kembar identik sekalipun sehingga membutuhkan perlakuan yang berbeda. Kejadian sama yang senantiasa berulang juga tidak sama, yaitu kombinasi kejadian jam 7.00 pagi hari ini tentu tidak sama dengan kombinasi kejadian jam 7.00 pagi kemarin dan esok, bahkan kejadian detik ini pun tidak akan sama dengan kejadian detik berikutnya, dan seterusnya. Begitulah Allah menciptakan segala sesuatu dengan unik, bahkan hanya ada "satu" di alam semesta.

Mengakui keunikan tiap-tiap kejadian adalah suatu cara untuk mengagungkan kesempurnaan ZatNya, yaitu dengan memperlakukan keunikan tersebut sesuai dengan keunikannya. Sebuah perlakuan terhadap sebuah benda atau kejadian yang unik tentu tidak bisa diterapkan pada benda atau kejadian yang lain. Di dalam sub bab sebelumnya telah dijelaskan bahwa setiap permasalahan sudah lengkap dengan solusinya, dimana solusi yang dimaksud ini bersifat unik, fokus, dan spesifik. Solusi yang satu tidak bisa menjadi solusi dari permasalahan lainnya. Walaupun solusi tersebut terlihat berbeda-beda pada setiap permasalahan, akan tetapi memiliki tujuan yang satu, yaitu menciptakan kemaslahatan. Inilah yang disebut oleh peneliti sebagai prinsip ke-satu-an (principle of one). Prinsip ini memandang bahwa keberagaman itu sebenarnya terikat oleh satu kesatuan tujuan, selama masih memiliki kesamaan tujuan maka keberagaman tersebut hendaknya diperlakukan secara spesifik sesuai dengan keunikan karakter dan kebutuhannya masing-masing. Kesatuan tujuan ini menunjukkan adanya keserasian dan keutuhan dalam keberagaman itu sendiri karena sebenarnya keberagaman itu berasal dari Yang Satu. Dengan demikian, kesamaan tujuan dalam prinsip ke-satu-an ini merupakan pengikat prinsip keserasian dan prinsip keutuhan. Semua aktifitas muamalah yang memiliki satu tujuan, yaitu kemaslahatan, pasti merupakan aktifitas yang terjaga keserasian dan keutuhannya, berdzikir. Semua lafadz dzikir yaitu tasbih, tahmid, tahlil dan takbir sebenarnya adalah satu lafadz, yaitu Allah.

Principle of one ini berlaku dalam aktifitas muamalah. Beberapa akad muamalah, misalnya : murabahah, mudharabah, musyarakah, dan salam, tentunya memiliki mekanisme yang berbeda sesuai dengan fungsinya masing-masing untuk merumuskan produk-produk keuangan syariah yang dapat digunakan oleh masyarakat. Akad murabahah adalah solusi bagi mereka yang ingin membeli aset dengan cicilan tetap tanpa riba. Akad mudharabah dan musyarakah adalah solusi bagi pihak-pihak yang ingin berinvestasi dalam sebuah bisnis. Begitu pula dengan akad salam yang menjadi solusi bagi para petani yang ingin menjual hasil panennya sebelum panen untuk mendapatkan pembiayaan modal kerja. Walaupun mekanisme dan kegunaannya berbeda, akad-akad tersebut sebenarnya memiliki kesamaan tujuan, yaitu mewujudkan perniagaan yang suka-sama-suka di antara pihak-pihak yang bertransaksi 
(tijaratan antaradhin minkum) sebagaimana QS. An-Nisa' ayat 29. Perniagaan yang demikian pada akhirnya dapat menghindarkan aktifitas muamalah tersebut dari praktik ribawi yang dilarang dalam Islam.

\section{Berdzikir adalah Berpikir Terbalik (Reversed Thinking).}

Berdzikir akan membawa kita kepada sebuah perasaan dimana Allah begitu dekat dengan diri kita sehingga membuat kita melupakan yang selain Allah. Allah memang memerintahkan kita untuk senantiasa ingat dan bergantung hanya padaNya, sehingga tidak bergantung sedikitpun kepada mahluk, sebagaimana firman-firman Allah sebagai berikut :

"Hanya Engkaulah yang kami sembah, dan hanya kepada Engkaulah kami meminta pertolongan." (QS. Al-Fatihah:5)

"Allah adalah Tuhan yang bergantung kepada-Nya segala sesuatu." (QS. Al-Ikhlas:2)

"Hai manusia, kamulah yang berkehendak kepada Allah, dan Allah Dialah Yang Maha Kaya (tidak memerlukan sesuatu) lagi Maha Terpuji.” (QS. Fathir:15)

Dzikir yang berkualitas, yaitu yang menyeluruh mulai dari hulu ke hilir, dimulai dari lisan, pikiran dan hati, serta tindakan, akan menimbulkan sikap ketergantungan hanya kepada Allah, yang disebut dengan tawakal (tawakkal). Orang-orang yang bertawakal adalah orang-orang yang tidak takut kepada siapapun dan apapun kecuali hanya takut kepada Allah (QS. Ali Imran:175), serta merasa cukuplah Allah menjadi penolong dan sebaik-baik pelindung (QS. Ali Imran:173). Keberanian untuk bertawakal ini timbul karena Allah memang berjanji untuk mencukupkan segala keperluan bagi siapa saja yang mau berserah diri hanya kepadaNya, sebagaimana firmanNya dalam QS. At-Talaq:3 :

\section{"Dan barangsiapa yang bertawakal kepada Allah, niscaya Allah akan mencukupkan segala keperluannya."}

Akan tetapi, seringkali manusia lupa dan menggantungkan hidupnya pada selain Allah, dengan kata lain manusia seringkali menciptakan tuhan-tuhan yang lain dan bergantung kepadanya. Tuhan-tuhan yang lain itu bisa berupa harta, kekuasaan, dan segala kenikmatan duniawi lainnya. Manusia seringkali lebih takut kehilangan uang daripada mengingat perintah Allah untuk menghindari riba. Manusia seringkali lebih takut kehilangan jabatan dengan lebih mementingkan jadwal rapat daripada jadwal sholat. Bila demikian yang terjadi, maka sebenarnya manusia tersebut sudah menuhankan yang selain Allah, sudah bergantung kepada selain Allah, lebih takut kehilangan dunia daripada kehilangan Allah, sehingga bisa dikatakan manusia tersebut sedang tidak berdzikir kepada Allah. Kondisi inilah yang merupakan sebab kerusakan di langit dan bumi, sebagaimana firmanNya dalam QS. Al-Anbiya:22 :

"Sekiranya ada di langit dan di bumi tuhan-tuhan selain Allah, tentulah keduanya itu telah rusak binasa. Maka Maha Suci Allah yang mempunyai "Arsy daripada apa yang mereka sifatkan."

Dengan demikian, penerapan ketiga prinsip dzikir yang saling terikat satu dengan lainnya sebagaimana digali dalam sub bab sebelumnya, yaitu : prinsip keserasian, prinsip keutuhan, dan prinsip ke-satu-an, akan menimbulkan sikap berani melupakan yang selain Allah dan hanya bergantung (tawakkal) kepadaNya. Berani untuk melupakan yang selain Allah berarti berani untuk tidak menggantungkan diri kepada ciptaanNya, yaitu alam semesta, dunia, dan seisinya. Bila dunia dan seisinya dirasa lebih membawa kerusakan daripada kemaslahatan, maka manusia yang berdzikir akan berani untuk melupakan ketergantungannya kepada dunia dan mencari jalan untuk kembali kepada Allah.

Pada hakikatnya, semua adalah ciptaan Allah, sehingga alam semesta dan segala kejadian di dalamnya adalah milik Allah dan tentunya akan kembali kepada Allah, innalillahi wa inna illaihi roji'un yang artinya sesungguhnya kami adalah milik Allah dan akan kembali kepada Allah (QS. Al- 
Baqarah:156). Ayat ini mengilhami filsafat Manunggaling Kawulo-Gusti yang diajarkan seorang tokoh sufi besar yang kontroversial di jamannya, yaitu Syaikh Siti Jenar. Ajaran ini terkait dengan konsep sangkan paraning dumadi, asal mula dan arah tujuan semua kejadian, yaitu memahami bahwa segala sesuatu berasal dari Allah dan berakhir pada Allah (Triyuwono, 2015:368; Djaya, 2003:31).

Bila semua berasal dari Allah dan akan kembali kepadaNya, maka hakikat kehidupan dengan segala aspek di dalamnya adalah sebuah perjuangan untuk menemukan jalan untuk "kembali" kepada Allah. Kata "kembali" ini mengandung makna kesengajaan untuk menghentikan perjalanan yang sedang dilakukan dan berputar kembali menuju awal perjalanan. Bila materialisme adalah sebuah kesadaran yang sering mewarnai perjalanan hidup manusia di dunia, maka " berhenti dan berputar kembali" berarti berani untuk melepaskan ketergantungan pada materialisme. Keberanian untuk tidak bergantung kepada materialisme ini bisa diterjemahkan sebagai keberanian untuk berpikir "melawan putaran arus" keduniawian. Filosofi putaran arus keduniawian terlihat pada putaran benda-benda di dunia yang berputar ke kanan searah jarum jam (clock-wise), sebagaimana terlihat dalam putaran ulir tutup botol minuman, putaran mur, serta putaran kran air yang bila diputar ke kanan akan semakin menutup atau mengeras, sebagaimana kesepakatan para ahli manufaktur di seluruh dunia. Arus keduniawian juga terlihat pada aliran arus sungai yang berawal dari mata air menuju ke muara, dimana makin ke muara makin keruh airnya. Begitulah putaran dan arus dunia, makin diikuti makin membawa manusia jauh dari Allah, makin lupa kepadaNya, sehingga makin dekat dengan kerusakan daripada kemaslahatan. Kemaslahatan akan diperoleh dengan cara berani "melawan arus" dunia dengan tujuan kembali mendekat kepada Allah agar mendapatkan kecukupan dan keberuntungan dariNya, sebagaimana arus putaran thawaf yang tidak searah jarum jam (anti-clock-wise).

Arus dan putaran dunia bisa diterjemahkan sebagai sistem atau peraturan yang dibuat oleh manusia dimana sarat dengan nilai yang dianutnya saat membuat sistem atau peraturan tersebut, atau bisa juga sebuah aktifitas yang sudah biasa dilakukan. Sepanjang "sesuatu" itu melibatkan manusia, maka sesuatu itu pasti subyektif dan konsekuensinya sarat nilai (value ladden) (Triyuwono, 2015:389). Bila sistem, peraturan, atau kebiasaan tersebut sudah tidak bisa mengakomodasi kebutuhan untuk membawa maslahat, maka diperlukan keberanian untuk berpikir terbalik (reversed thinking), tidak biasa, "melawan arus", out-of-the system, out-of-the box, atau disebut juga berpikir inovatif. Lindung nilai adalah sebuah upaya untuk menghindari kerugian akibat fluktuasi harga komoditi, dimana secara tidak langsung memelihara keuntungan yang didapatkan seorang pelaku pasar perdagangan komoditi. Bila belum terdapat sebuah produk, mekanisme, atau regulasi yang mengakomodasi praktik lindung nilai secara Islami, maka dibutuhkan keberanian untuk berinovasi dengan cara berpikir out-of-the box bahkan out-ofthe system demi mencari solusinya. Realitas maraknya transportasi online (Go-Jek, Uber, Grab), toko online (OLX, Lazada, Shopee, JD.id), dan financial technology (peer-to-peer lending) adalah beberapa hasil dari berpikir terbalik, tidak biasa, inovatif, yang mampu menembus batas regulasi yang ada. Bila menunggu keluarnya payung regulasi, maka realitas yang terbukti mampu memberdayakan masyarakat luas tersebut belum tentu bisa terwujud. Dengan demikian, lindung nilai yang berdzikir adalah lindung nilai yang dilakukan dengan inovatif sesuai dengan petunjuk dari Al-Qur'an dan As-Sunnah walaupun terkadang harus berani menembus batas regulasi yang ada.

Pada intinya, segala permasalahan yang terjadi pada aktifitas muamalah disebabkan karena tidak menerapkan prinsip dzikir. Penerapan ketiga prinsip dzikir, yaitu : prinsip keserasian, prinsip keutuhan, dan prinsip ke-satu-an, dalam aktifitas muamalah akan mengembalikan aktifitas muamalah tersebut kepada keserasian supply chain-nya dari hulu ke hilir, mengembalikan keutuhan mekanismenya, dan mengembalikan keberagaman kepada tujuan yang satu, yaitu kemaslahatan. Kuncinya terletak pada kata "kembali" yang bermakna pembalikan arah menuju asal usulnya yang serasi, utuh, dan satu tujuan. Pencarian solusi dari permasalahan lindung nilai (hedging) nantinya dilakukan dengan menggunakan filosofi berpikir terbalik (reversed thinking) melalui penerapan ketiga prinsip dzikir tersebut, baik secara simultan maupun parsial.

\section{Perdagangan Berjangka Komoditi : Berdzikirlah dengan Physical Delivery.}


Pencarian "jalan kembali" untuk lindung nilai komoditi dengan menggunakan reversed thinking ini bermula saat penulis menemukan berbagai permasalahan dalam praktik perdagangan berjangka komoditi di Indonesia. Perdagangan berjangka yang seharusnya digunakan sebagai sarana lindung nilai pada praktiknya lebih banyak digunakan sebagai sarana berspekulasi dengan cara memperdagangkan kontrak berjangka tanpa bermaksud sama sekali untuk melakukan serah terima fisik komoditi. Hal ini terlihat dari laporan transaksi perdagangan berjangka komoditi yang menunjukkan bahwa transaksinya 95\% adalah transaksi kontrak berjangka Sistem Perdagangan Alternatif (SPA) yaitu kontrak berjangka yang tidak melibatkan serah terima fisik komoditi (www.bappebti.go.id).

Badan Pengawas Perdagangan Berjangka Komoditi (Bappebti) sebagai regulator di bawah naungan Kementerian Perdagangan Republik Indonesia sudah mewajibkan kedua Bursa Berjangka komoditi di Indonesia, yaitu Bursa Berjangka Jakarta (Jakarta Futures Exchange/JFX) (www.jfx.co.id) dan Bursa Komoditi dan Derivatif Indonesia (Indonesia Commodity and Derivatives Exchange/ICDX) (www.icdx.co.id), untuk meluncurkan produk kontrak berjangka komoditi multilateral, sebagaimana tercantum dalam Peraturan Kepala Bappebti Nomor: 69/BAPPEBTI/PER/6/2009 Pasal 4 ayat 3 dan Pasal 6 berikut ini :

"Setiap Penyelenggara Sistem Perdagangan Alternatif wajib melaksanakan transaksi Kontrak Berjangka Multilateral di Bursa Berjangka paling sedikit 5\% (lima persen) dari total transaksi setiap bulan." (Pasal 4 ayat 3)

"Setiap pihak yang melanggar Peraturan Kepala Badan Pengawas Perdagangan Berjangka Komoditi ini, dikenakan sanksi administratif sebagaimana diatur dalam Undang-Undang Nomor 32 Tahun 1997 tentang Perdagangan Berjangka Komoditi dan peraturan perlaksanaannya." (Pasal 6)

Komoditi multilateral adalah kontrak berjangka yang ditransaksikan di dalam bursa (exchange traded) sehingga harga yang terjadi mencerminkan permintaan dan penawaran terhadap kontrak tersebut. Perdagangan komoditi multilateral diharapkan bisa menjalankan fungsi price discovery komoditikomoditi primer di Indonesia, sehingga menjadikan Indonesia sebagai pembentuk harga acuan beberapa komoditi primer, yaitu : kelapa sawit, kakao, kopi, dan komoditi lainnya. Selain itu, perdagangan kontrak komoditi multilateral bisa menjadi sarana lindung nilai (hedging) bagi para pelaku pasar komoditi.

Penyelenggara Pasar (market maker) berperan penting untuk memastikan perdagangan komoditi multilateral bisa terjadi di bursa berjangka komoditi. Hal ini disebabkan karena Penyelenggara Pasar bertugas untuk memasang amanat beli dan/atau amanat jual secara terus menerus selama jam perdagangan untuk memastikan likuiditas pasar.

"Dalam Peraturan Kepala Badan Pengawas Perdagangan Berjangka Komoditi ini yang dimaksud dengan Penggerak Pasar adalah pihak yang memasang amanat beli dan/atau amanat jual secara terus menerus selama jam perdagangan berlangsung." (Peraturan Kepala Bappebti Nomor: 69/BAPPEBTI/PER/6/2009, Pasal 1 butir 1)

Tetapi hingga saat ini, Bappebti belum istiqamah menjalankan perannya untuk mengarahkan aktifitas perdagangan berjangka komoditi sebagai sarana lindung nilai. Hal ini terlihat dalam hasil indepth interview dengan Commodity Desk Officer salah satu perusahaan pialang berjangka terbesar di Indonesia, yang selanjutnya disebut key informant, berikut ini :

"Regulator (Bappebti) itu sepertinya ndak serius ngurusi transaksi komoditi multilateral, transaksinya ya wes gini-gini aja, sekedar diada-adakan transaksinya untuk menggugurkan kewajiban jumlah transaksi minimal 5\% dari transaksi SPA (transaksi over-the-counter) tiap bulan. Itupun ndak konsisten dengan aturan yang dibuatnya, karena ada pialang lain yang transaksinya kurang dari 5\% juga ndak ada sanksinya." 
Ketidakkonsistenan Bappebti dalam mendukung transaksi lindung nilai terbukti dengan belum adanya sanksi yang diberikan kepada pialang berjangka yang belum memenuhi persyaratan jumlah minimal transaksi komoditi multilateral. Hal ini mengakibatkan ketidakseriusan para fasilitator perdagangan berjangka komoditi, yaitu pialang berjangka, bursa berjangka, dan penyelenggara pasar (market maker) untuk mendukung terciptanya transaksi lindung nilai. Pialang berjangka menjadi tidak serius dalam menawarkan produk kontrak berjangka multilateral kepada nasabahnya, dan bursa berjangka juga tidak konsisten "memaksa" penyelenggara pasar untuk senantiasa memasang amanat beli dan/atau jual selama jam perdagangan. Akibatnya, pasar menjadi tidak likuid. Ketidaklikuidan pasar ini akan menyebabkan para nasabah pialang berjangka yang serius menawarkan lindung nilai kesulitan untuk menemukan lawan transaksi dalam rangka membuka posisi pada harga yang diinginkan, hingga akhirnya harga berubah dan jam perdagangan ditutup, sebagaimana hasil in-depth interview dengan key informant berikut ini :

"Waktu itu saya pasang posisi buy 1 lot kontrak berjangka emas di bursa ICDX, pagi pasangnya, ditunggu lama nggak juga matched (dapat lawan transaksi), lha wong ndak ada yang nge-bid dan ngeoffer, sampai akhirnya pasar tutup dan posisinya ilang, besoknya tak ulangi lagi, tetep podo ae."

Kondisi ini dapat membuat nasabah memutuskan untuk tidak bertransaksi lagi dan menarik semua dananya (withdraw). Pada akhirnya, ketidakpuasan nasabah ini bisa menjadi alasan bagi pialang untuk tidak lagi menawarkan sarana lindung nilai dengan komoditi multilateral kepada nasabahnya.

Permasalahan dalam mekanisme lindung nilai melalui perdagangan berjangka komoditi adalah akibat dari tidak diterapkannya prinsip keserasian (principle of harmony). Peraturan Kepala Bappebti tentang jumlah minimal transaksi komoditi multilateral beserta sanksinya dan kewajiban pemasangan amanat beli dan/atau jual oleh peyelenggara pasar adalah upaya untuk membentuk keserasian antara regulator (Bappebti), bursa berjangka, penyelenggara pasar, pialang berjangka, dan nasabah. Bila aturan tersebut diimplementasikan dengan benar, maka pialang berjangka akan berusaha sebaik mungkin untuk menawarkan produk lindung nilai, dan bursa berjangka akan memfasilitasi transaksi semaksimal mungkin dengan "memaksa" penyelenggara pasar untuk memasang amanat beli dan/atau jual selama jam perdagangan. Keserasian ini akan menciptakan likuiditas pasar sehingga nasabah mudah untuk mendapatkan lawan transaksi. Tidak diberlakukannya sanksi yang tegas oleh Bappebti akhirnya memutus keserasian mekanisme ini sehingga pasar menjadi tidak likuid.

Pasar yang likuid akan menarik banyak nasabah untuk bertransaksi. Semakin meningkat keberagaman nasabah yang bertransaksi akan meningkatkan kemungkinan terjadinnya transaksi lindung nilai antara pelaku lindung nilai (hedger) dengan pelaku lindung nilai (hedger), yaitu antara buying hedger dan selling hedger. Dengan semakin meningkatnya transaksi antara hedger dengan hedger maka kemungkinan terjadinya serah terima fisik saat kontrak jatuh tempo akan semakin besar. Serah terima fisik saat kontrak berjangka jatuh tempo adalah indikator utama terjadinya lindung nilai, dimana penjual akan menyerahkan komoditinya dan pembeli akan membayar lunas kepada penjual. Bila di akhir kontrak pembeli sudah siap dengan pembayaran dan ternyata penjual gagal serah komoditi, hal ini menunjukkan bahwa mekanisme lindung nilai belum berjalan. Inilah yang terjadi di perdagangan berjangka komoditi di Indonesia, sebagaimana terlihat dari hasil in-depth interview dengan key informant berikut ini :

"Kapan itu ketemu teman broker dari perusahaan pialang berjangka "Pandawa" (nama samaran), saya ucapkan selamat karena transaksi komoditi multilateralnya sudah bagus, tapi katanya semua nasabahnya ndak bisa serah terima fisik komoditi emas di Pegadaian (tempat serah terima fisik emas yang ditunjuk resmi oleh bursa berjangka), alasannya barangnya ndak ada."

Permasalahan gagal serah komoditi oleh penjual di akhir masa kontrak tersebut menunjukkan ketidakserasian antara pembeli dan penjual, pembeli bermaksud untuk lindung nilai akan tetapi penjual bisa jadi hanya bermaksud untuk berspekulasi dengan tidak melibatkan fisik komoditi. Untuk mengatasi ketidakserasian ini diperlukan regulasi yang tegas agar bisa menjamin terjadinya serah terima fisik. Regulasi ini diharapkan bisa memastikan bahwa pihak pembeli dan penjual bermaksud untuk melakukan 
lindung nilai dengan serah terima fisik di akhir kontrak. Bila tidak dimungkinkan dilakukan dengan kontrak berjangka multilateral yang masih bersifat seller's-choice physical delivery (serah terima fisik berdasarkan permintaan penjual; Kontrak Berjangka) atau buyer's-choice physical delivery (serah terima fisik berdasarkan permintaan pembeli; Kontrak Berkala) di Bursa Berjangka Jakarta (www.jfx.co.id), maka bisa dilakukan dengan mengeluarkan produk kontrak baru yang buyer's seller's-choice physical delivery (serah terima fisik sesuai permintaan bersama antara pembeli dan penjual) sehingga ada kepastian terjadinya perpindahan kepemilikan komoditi dari penjual kepada pembeli. Perpindahan kepemilikan merupakan syarat utama perniagaan yang sesuai dengan syariat Islam. Perniagaan yang demikian akan terjadi apabila ada keserasian antara pembeli dan penjual. Pasar yang likuid dan dukungan regulasi akan bisa mewujudkannya.

Memastikan perpindahan kepemilikan komoditi dari penjual kepada pembeli melalui serah terima fisik komoditi saat kontrak jatuh tempo merupakan sebuah langkah untuk mengembalikan keutuhan mekanisme transaksi sebagaimana prinsip keutuhan (principle of integrity). Spesifikasi kontrak berjangka yang mengandung ketidakpastian serah terima fisik komoditi merupakan pemisahan antara resiko dari aktifitas perdagangannya. Pemisahan ini terjadi karena adanya kepentingan dari hedger untuk mentransfer resiko fluktuasi harga komoditi kepada lawan transaksinya. Bila resiko ini hanya ditransfer, maka sebenarnya resiko tersebut masih belum terkelola, hanya berpindah kepada lawan transaksi dan masih dapat mengakibatkan kerugian. Risk transfer adalah aktifitas zero-sum dimana keuntungan salah satu pihak yang bertransaksi mengakibatkan kerugian bagi lawan transaksinya. Islam mengajarkan bahwa perniagaan itu harus berprinsip suka-sama-suka (win-win situation) di antara pihak yang bertransaksi, tijaaratan antaradhin minkum (QS. An-Nisa':29). Karena menanggung potensi kerugian yang dipindahkan oleh hegder, maka lawan transaksi akan berusaha bagaimana agar tidak rugi dengan cara segera melikuidasi atau mengakhiri posisinya saat mendapatkan keuntungan berdasarkan perhitungan daily mark-to-market (perhitungan untung-rugi harian dari posisi terbuka). Transaksi dalam perdagangan berjangka komoditi bisa diakhiri dengan dua cara, yaitu : melikuidasi posisi (offsetting) atau membiarkan kontrak berakhir dengan serah terima fisik (physical delivery). Bila salah satu pihak melikuidasi posisinya sebelum kontrak berakhir, maka pihak tersebut sebenarnya sedang memindahkan resikonya kepada pihak lain. Likuidasi posisi sebelum jatuh tempo kontrak berjangka adalah sebuah aktifitas trading sebagaimana dilakukan oleh spekulan dimana motif transaksinya adalah berspekulasi untuk mendapatkan keuntungan, bukan untuk berlindung nilai. Dengan demikian, mekanisme lindung nilai yang seharusnya terjadi antara hedger dengan hedger akhirnya menjadi sebuah transaksi antara hedger yang berharap serah terima fisik komoditi dengan spekulan yang tidak mengharapkan untuk melibatkan fisik komoditi.

"The instrument of derivatives allow risk related to the price of the underlying asset to be transferred from one party to another. This is due to derivatives contract involves one party reducing its risk, and the other taking on risk associated with an underlying asset. This allows parties to speculate on the values of underlying assets, without necessarily having any actual interest in the asset itself." (Ahmad and Halim, 2014)

Ketidakserasian ini timbul karena adanya ketidakutuhan dalam mekanisme perdagangan berjangka komoditi akibat pemisahan antara resiko dengan aktifitas perdagangannya. Pemisahan ini menimbulkan ketidakpastian perpindahan kepemilikan komoditi dari penjual kepada pembeli.

Perbedaan kepentingan atau tujuan antara regulator dan para pelaku pasar, yaitu Bappebti, bursa berjangka, pedagang berjangka, pialang berjangka, dan nasabah, menyebabkan ketidakserasian dan ketidakutuhan mekanisme transaksi di dalam perdagangan berjangka komoditi. Bursa berjangka dan pialang berjangka yang pendapatannya masih bergantung pada jumlah transaksi SPA (Sistem Perdagangan Alternatif) tentunya akan cenderung untuk sekedar "bermain aman" dengan jumlah minimal lot transaksi komoditi multilateral. Pedagang berjangka sebagai penyelenggara pasar di lain pihak berorientasi keuntungan untuk dirinya sendiri sehingga pasar yang masih baru dan belum banyak "pemainnya" tentunya tidak akan menarik baginya. Kewajiban untuk selalu memasang amanat beli dan/atau jual selama jam perdagangan komoditi multilateral akan berujung pada "insentif' apa yang akan 
didapatkan oleh pedagang berjangka. Bappebti yang seharusnya berperan untuk menggalang kesatuan tujuan ternyata belum juga memiliki "keberpihakan" kepada transaksi untuk lindung nilai. Hal ini terlihat dari hasil in-depth interview dengan key informant berikut ini :

"Sebenarnya sebabnya juga dari regulator (Bappebti) sendiri kenapa kok mengijinkan transaksi komoditi multilateral yang ndak bisa serah terima fisik (kontrak berjangka gulir) jadinya ya sama aja dengan transaksi SPA.”

Hasil wawancara tersebut menunjukkan bahwa Bappebti hingga saat ini masih berpihak pada transaksi SPA yang bersifat over-the-counter (OTC) yang terdiri dari produk-produk kontrak berjangka yang sifatnya gulir dan tanpa serah terima fisik, yaitu : forex, stock index, loco London gold (XAUUSD), kontrak gulir emas (GoldUD, GoldID) yang harganya mengacu pada harga emas London (www.jfx.co.id ; www.icdx.co.id). Tidak adanya serah terima fisik membuat kontrak-kontrak tersebut memiliki kecenderungan untuk ditransaksikan oleh spekulan dengan motif mencari keuntungan, bukan untuk berlindung nilai. Keberpihakan Bappebti pada transaksi OTC juga terlihat dari kutipan Peraturan Kepala Bappebti berikut ini :

"Sebelum ketentuan dalam Peraturan ini berlaku untuk semua Pihak, Bappebti terlebih dahulu menetapkan Pihak yang melakukan Pilot Project dalam rangka pelaksanaan penerimaan Nasabah secara elektronik on-line hanya untuk transaksi Kontrak Derivatif selain Kontrak Berjangka dan Kontrak Derivatif Syariah dalam Sistem Perdagangan Alternatif dengan volume minimum 0,1 (nol koma satu) lot untuk jangka waktu 1 (satu) tahun sejak Peraturan ini diundangkan berdasarkan Keputusan Kepala Badan Pengawas Perdagangan Berjangka Komoditi." (Peraturan Kepala Bappebti Nomor: 99/BAPPEBTI/PER/11/2012, Pasal 4 ayat 1)

Pemberlakuan volume minimum transaksi SPA (OTC) sebesar 0,1 lot dalam kebijakan penerimaan nasabah secara online pada tahun 2012 menjadi trigger untuk penyebaran transaksi SPA kepada nasabahnasabah yang illegible. Transaksi SPA adalah transaksi kontrak berjangka yang memiliki leverage yang tinggi sehingga seharusnya hanya bisa dilakukan oleh nasabah-nasabah yang memiliki investment knowledge dan financial situation yang baik. Nasabah yang berkarakter demikian adalah nasabah yang memiliki kemampuan untuk membuka rekening perdagangan dengan intial margin minimal Rp.100.000.000,- (seratus juta rupiah) untuk bisa bertransaksi minimal 1 lot (lot standar). Terbukanya kebijakan untuk bertransaksi 0,1 lot (lot mini) akan menyebabkan masuknya nasabah-nasabah yang bermodal Rp.5.000.000,- (lima juta rupiah) hingga Rp.10.000.000,- (sepuluh juta rupiah) untuk bertransaksi dengan motif spekulasi pada kontrak ber-leverage tinggi. Nasabah-nasabah yang demikian adalah nasabah-nasabah yang memiliki kecenderungan untuk memakai cadangan dana kebutuhan daruratnya untuk bertransaksi, dan tentunya dengan pengetahuan investasi yang masih rendah sehingga selalu berharap untung dan tidak mau rugi. Pengetahuan investasi yang rendah akan mengakibatkan kecenderungan nasabah lot mini ini untuk berakhir dengan kerugian karena ketidaksiapan mental menghadapi transaksi yang high leverage. Hal ini semakin memperburuk image perdagangan berjangka komoditi yang beberapa tahun yang lalu sudah sempat masuk dalam daftar "investasi bodong" yang dirilis oleh Otoritas Jasa Keuangan (OJK) (www.ojk.go.id). "Lingkaran kejadian" ini akan berputar terus menerus apabila tidak terjadi kesatuan tujuan antara regulator dan pelaku pasar.

Memastikan perpindahan kepemilikan komoditi melalui serah terima fisik (physical delivery) akan mengembalikan mekanisme transaksi kepada tujuan yang satu yaitu lindung nilai, dimana tidak memisahkan antara resiko dengan aktifitas perdagangannya, sebagaimana prinsip ke-satu-an (principle of one).

"The risk acceptable in Islam is the one that follows the economic activities and the one that generates returns, rather than unprofitable risk detrimental to the economic activities. " (Suwailem, 2006) 
"The sole objective of Islamic hedging in reducing risks must relate only with real economic activities." (Ahmad and Halim, 2014)

Transaksi yang terjadi antara pembeli yang ingin mendapatkan komoditi (buying hedger) dan penjual yang ingin menjual komoditi yang dimilikinya (selling hedger) akan menimbulkan kepastian serah terima fisik. Dan instrumennya adalah regulasi yang "berpihak".

Perpindahan kepemilikan ini sebenarnya merupakan perdagangan fisik komoditi, bukan perdagangan berjangka komoditi. Kata "berjangka" dalam perdagangan berjangka komoditi adalah sebuah simbol pemisahan antara perdagangan komoditi dengan resikonya. Perdagangan komoditinya terjadi di pasar fisik (spot market) sedangkan resikonya diperdagangkan di pasar berjangka (futures market). Dengan demikian, solusi mekanisme lindung nilai yang sesuai dengan syariat Islam ada di dalam perdagangan komoditi di pasar fisiknya, bukan di pasar berjangkanya. Selama masih menggunakan istilah "berjangka", maka serah terma fisik komoditi masih belum menjadi "kewajiban" dalam perdagangan berjangka komoditi. Bila serah terima fisik masih hanya menjadi pilihan, maka kepastian perpindahan kepemilikan tidak akan pernah terwujud, sehingga perdagangan berjangka komoditi belum bisa dikatakan "berdzikir" karena tidak menerapkan prinsip keserasian, prinsip keutuhan, dan prinsip ke-satu-an dalam mekanisme perdagangannya.

Lindung nilai (hedging) yang "berdzikir" adalah lindung nilai yang disertai dengan kepastian perpindahan kepemilikan melalui serah terima fisik komoditi. Dengan demikian, lindung nilai tersebut tidak terpisah dengan aktifitas perdagangan riilnya, karena resiko senantiasa melekat pada aktifitas bisnis yang menghasilkan keuntungan.

"It can be concluded that the theory of Islamic hedging is to be in accordance with the hadith of al-kharaj bi al-daman and figh maxim of al-ghunm bi al-ghurm. Al-Ghunm bi al-ghurm is one of the famous Islamic legal principle which means returns are justified by taking risks. The principle refers to one is entitled to a gain only if one agrees to bear the responsibility for the loss. Thus, earning profit is legitimised only by risk-sharing and engaging in an economic venture. Islamic hedging first and foremost recognizes the importance of risk-taking, rather than evading it. The profits made without risk-taking is not permissible in Islam. Economic activities carried out must also be linked solely to real economic activities.” (Ahmad and Halim, 2014; Ayub, 2007)

Keuntungan yang didapatkan tanpa adanya pengambilan resiko tidak dibenarkan dalam Islam, sebagaimana prinsip al-kharaj bi al-daman, al-ghunm bi al-ghurm, no pain no gain. Resiko itu untuk dikelola, bukan untuk dihilangkan. Cara terbaik untuk mengelola resiko adalah dengan mengambil dan saling membagi resiko (risk sharing), bukan memindahkan resiko (risk transfer) sebagaimana yang terjadi dalam perdagangan berjangka komoditi. Penerapan ketiga prinsip dzikir pada upaya pencarian solusi lindung nilai akan mengarahkan pada perdagangan dimana pihak-pihak yang bertransaksi saling membagi resiko (risk sharing). Risk sharing hanya bisa terjadi apabila ada kesamaan tujuan antara pembeli dan penjual untuk mengelola resiko (prinsip ke-satu-an). Kesamaan tujuan akan menimbulkan komitmen antara pembeli dan penjual untuk melakukan serah terima fisik yang didukung oleh regulasi untuk menciptakan pasar yang likuid (prinsip keserasian), sehingga keutuhan mekanisme perdagangan yang melibatkan pelaku pasar, pasar/bursa, dan regulator akan terjaga. Keutuhan peran para stakeholder perdagangan komoditi inilah yang akan memunculkan solusi dari lindung nilai tanpa harus memisahkan antara resiko dengan aktifitas perdagangannya (prinsip keutuhan). "Karena sesungguhnya sesudah kesulitan itu ada kemudahan, sesungguhnya sesudah kesulitan itu ada kemudahan." begitulah firman Allah dalam QS. Al-Insyirah ayat 5-6.

\section{Simpulan}

Perdagangan Berjangka Komoditi di Indonesia diselenggarakan oleh pemerintah di bawah naungan Badan Pengawas Perdagangan Berjangka Komoditi (Bappebti) dengan tujuan sebagai sarana pembentukan harga komoditi primer (price discovery) dan sebagai sarana lindung nilai (hedging) dengan 
menggunakan kontrak berjangka (futures contract). Akan tetapi, praktik perdagangan berjangka saat ini hanya menjadi sarana spekulasi yang disebabkan oleh spesifikasi dan mekanisme transaksinya.

Lindung nilai dengan menggunakan kontrak berjangka adalah lindung nilai yang dilakukan dengan cara mengalihkan resiko salah satu pihak kepada pihak lainnya, karena kontrak berjangka diperdagangkan dengan sistem zero-sum. Oleh karena itu, lindung nilai dengan menggunakan kontrak berjangka dikategorikan sebagai aktifitas transfer resiko (risk transfer). Dalam Islam, mitigasi resiko seharusnya dilakukan dengan cara mengelola resiko bersama atau risk sharing, dimana dalam hal ini pihak pembeli dan penjual akan menanggung dan mengelola resiko secara bersama-sama dan tidak ada pihak yang lebih dirugikan karena harus menanggung resiko dari pihak yang lain. Risk transfer akan menimbulkan win-lose situation, sedangkan risk sharing akan menimbulkan win-win situation. Karena risk transfer bisa menimbulkan win-lose situation dimana ada pihak yang akan dirugikan, maka hal ini membuka kesempatan bagi pihak penanggung resiko untuk melakukan upaya-upaya apapun agar tidak rugi, termasuk di dalamnya adalah menghalalkan segala cara.

Risk transfer dengan menggunakan kontrak berjangka mengandung sebuah pengertian bahwa kedua belah pihak, baik pembeli maupun penjual, saling membebankan resiko yang timbul dari fluktuasi harga komoditi. Apabila timbul resiko pada pembeli, maka pihak penjual lah yang harus menanggung resikonya, dan begitu pula sebaliknya. Oleh karena itu, kontrak berjangka dibuat dengan spesifikasi yang memungkinkan pihak-pihak yang bertransaksi untuk melikuidasi posisinya setiap saat dan pada harga berapa pun tanpa harus melibatkan proses serah-terima fisik komoditi yang bersangkutan. Sehingga, pihak pembeli yang awalnya ingin mendapatkan barang, begitu juga pihak penjual yang awalnya ingin menjual barangnya, pada akhirnya terekspos pada sebuah situasi ketidakpastian akan harga serta proses serah-terima fisik komoditi.

Penerapan ketiga prinsip dzikir, yaitu : prinsip keserasian (principle of harmony), prinsip keutuhan (principle of integrity), dan prinsip ke-satu-an (principle of one) pada upaya pencarian solusi lindung nilai dalam perdagangan berjangka komoditi akan mengarahkan pada perdagangan dimana pihakpihak yang bertransaksi saling membagi resiko (risk sharing). Risk sharing hanya bisa terjadi apabila ada kesamaan tujuan antara pembeli dan penjual untuk mengelola resiko (prinsip ke-satu-an). Kesamaan tujuan akan menimbulkan komitmen antara pembeli dan penjual untuk melakukan serah terima fisik yang didukung oleh regulasi untuk menciptakan pasar yang likuid (prinsip keserasian), sehingga keutuhan mekanisme perdagangan yang melibatkan pelaku pasar, pasar/bursa, dan regulator akan terjaga. Keutuhan peran para stakeholder perdagangan komoditi inilah yang akan memunculkan solusi dari lindung nilai tanpa harus memisahkan antara resiko dengan aktifitas perdagangannya (prinsip keutuhan).

Lindung nilai (hedging) yang "berdzikir" adalah lindung nilai yang disertai dengan kepastian perpindahan kepemilikan melalui serah terima fisik komoditi (physical delivery). Dengan demikian, lindung nilai tersebut tidak terpisah dengan aktifitas perdagangan riilnya, karena resiko senantiasa melekat pada aktifitas bisnis yang menghasilkan keuntungan.

\section{DAFTAR PUSTAKA}

Ahmad, Azlin A., Halim, Mustafa A., 2014, The Concept of Hedging in Islamic Financial Transactions, Journal of Asian Social Science, Vol. 10 No. 8.

al-Amine, M., \& al-Bashir, M., 2008, Risk Management in Islamic Finance: An Analysis of Derivatives Instruments in Commodity Markets, Pertama. Leidin: Brill's Arab \& Islamic Law Series.

al-Saati, \& Hameed, A. R. A., 2002, Sharia Compatible Futures, Journal King Abdulaziz University: Islamic Econ, 15(1), 3-25. 
Al-Tabari, 2000, Jami' Al-Bayan fi Ta'wil Al-Qur'an, Vol. 2, Beirut : Mu'assasah Al Risalah.

An-Nawawi, Riyadhus Shalihin Jilid 1, Penerjemah Achmad Sunarto, (Jakarta: Pustaka Imani, 1999) Cetakan IV.

Anwar, Muhammad, 1990, Islamic economic methodology. Journal of Objectives Studies, 2 (1), 2846.

Ayub, M., 2007, Understanding Islamic Finance. England: John Wiley \& Sons, Ltd.

Bacha, O. I., 2000, Asia's currency crisis: Between forex market inadequacies and currency vulnerability. In D.N. M. N. Hassan, \& M. Musa (Eds.), The Economic and Financial Imperatives of Globalization: An Islamic Response (pp. 41-89). Kuala Lumpur: Institut Kefahaman Islam Malaysia.

Bacha, O. I., 2004, Value preservation through risk management-a shariah compliant proposal for equity risk management. MPRA Research Paper 12632. Germany: University Library \& Munich.

Bakar, Osman, 1984, The Question of Methodology in Islamic Science. Muslim Education Quarterly, 2 (1), 16-30.

Borgherts, Donald M, 1996, The Encyclopedia of Philosophy Supplement. New York: Simon \& Schuster Macmillan.

Bungin, Burhan, 2012, Analisis Data Penelitian Kualitatif : Pemahaman Filosofis dan Metodologis ke Arah Penguasaan Model Aplikasi, Cetakan ke-8, PT. RajaGrafindo Persada, Jakarta.

Castelino, M.G., 1992, Hedge Effectiveness : Basis Risk and Minimum Variance Hegding, Journal of Futures Markets, vol.12(2), pp.187-201.

Chapra, M. Umer, 1996, What is Islamic economics. Jeddah: IRTI - IDB. Fox, Glen. (1997). Reason and reality in the methodologies of economics. UK: Edward Elgar.

Conrad, C., et al. 1993. Qualitative Research in Higher Education. Needham Heights MA: Giun Press.

Dewan Syariah Nasional MUI dan Bank Indonesia, 2006, Himpunan Fatwa Dewan Syariah Nasional MUI Cet. 3, Jakarta; CV. Gaung Persada.

Djaya, Ashad Kusuma, 2003, Pewaris Ajaran Syekh Siti Jenar : Membuka Pintu Makrifat, Yogyakarta : Kreasi Wacana

Elgari, \& Ali, M., 2010, Hedging mechanism in Islamic financial operations, Paper presented to the $7^{\text {th }}$ conference of Shariah Boards of the Islamic Financil Institutions-Auditing Unit for the Islamic Financial Institutions. Jeddah: King Abdul Aziz University.

Ferdiansyah, T, Roy Sembel, 2002, Sekuritas Derivativ, Edisi Pertama, Salemba Empat, Jakarta, Indonesia.

Folinas, D., Manikas, I. and Manos, 2006, B. ,Traceability data management for food chains, British Food Journal, Vol. 108 No. 8, pp 622. 
Global Islamic Finance Report, 2010, Global Islamic Finance, Annual Report.

Global Islamic Finance Report, 2010, Islamic derivatives, Theory and Practice, Global Islamic Finance.

Haider Ala Hamoudi, 2007, Muhammad's Social Justice or Muslim Cant? : Langdelleanism And The Failure Of Islamic Finance, Cornell International Law Journal, 40 Cornell International 89..

Holmes, P., 1995, Ex Ante Hedging Ratio and Hedging Effectiveness of the FTSE-100 Stock Index Futures Contract, Applied Economics Letters, vol.2(3), pp.56-59.

Hull, John C., 2002, Fundamentals of Futures and Options Markets, Prentice Hall Inc., Upper Saddle River, New Jersey.

2008, Futures, Options, and Other Derivatives, Prentice Hall Inc., Upper Saddle River, New Jersey.

IFSB, 2005, Guiding Principles of Risk Management for Institutions (Other than Insurance Institutions) Offering Only Islamic Financial Services, Exposure, Draft no. 1, www.ifsb.org

Jarrow, R., S. Turnbull, 2000, Derivative Securities, Second Edition, South-Western College Publishing, Ohio, USA.

Kahf, Monzer, 2003, Islamic economics: Notes on definition and methodology. Review of Islamic Economics, 13, 23-47, edition. Herndon, USA: IIIT.

Kamali, Muhammad Hashim, 1989, Source, nature and Objectives of Shari'ah. The Islamic Quarterly, 33 (4), 215-235.

Kamayanti, Ari, 2016, Metodologi Konstruktif Riset Akuntansi : Membumikan Religiositas, Cetakan Pertama, Yayasan Rumah Peneleh, Jakarta.

Karim, Adiwarman, 2003, Bank Islam : Analisis fiqh dan keuangan, Jakarta: IIIT Indonesia.

Khan, M. Fahim, 1997, Islamic Futures and Their Markets, with Special Reference to their Role in Developing Rural Financial Market, Research Paper No. 32, Islamic Research and Training Institute, Islamic Development Bank, Jeddah, Saudi Arabia.

Khan, T., \& Ahmed, H., 2001, Risk management: An analysis of issues in Islamic financial industry, Jeddah: Islamic Development Bank. Occasional paper, (5). Retrieved August 2, 2009.

Kolb, R. W., \& Overdahl, J. A., 2006, Understanding Futures Markets. Oxford: Blackwell Publishing.

Kolb, Robert W., 2000, Financial Derivatives, New York Institute of Finance, USA.

Laldin, M. A., \& Mokhtar, S., 2009, Risk management in Islamic finance. Kertas kerja Seminar Harvard-LSE Workshop on Risk Management. Islamic Economic and Islamic Ethico-Legal Perspectives on the Current Financial Crisis. London School of Economics.

Lindahl, M., 1992, Minimum Variance Hedge Ratios for Stock Index Futures : Durations and Expectation Effects, Journal of Futures Markets, vol.12(1), pp.33-53. 
Lindgreen, A. and Hingley, M., 2003, The impact of food safety and animal welfare policies on Supply Chain Management, British Food Journal Vol.105 No.6, pp 328-349.

Lubis, Akhyar Yusuf, 2004, Filsafat Ilmu dan Metodologi Postmodern, Bogor : Akademia.

Lyotard, Jean Francois. 1984, The Postmodern Condition: A. Report on Knowledge, Minneapolis: University of Minnesofa Press.

Machlup, Fritz, 1978, Methodology of economics and other social sciences. New York: Academic Press, Inc.

Majah, I., \& Al-Qazwini, M. I. Y. (1972). Sunan Ibn Majah. Beirut: Dar al-Jil.

Mardani, 2013, Fiqh Ekonomi Syariah : Fiqh Muamalah, Cetakan Kedua, Kencana Prenadamedia Group, Jakarta, Indonesia.

Mohamad, S., \& Ali, T., 2008, Islamic hedging: Gambling or risk management?, Islamic Law and the Law of the Muslim World, 8-47. 21 st Australian Finance and Banking Conference.

Muhadjir, Noeng, 1982, Teori Perubahan Sosial, Yogyakarta : Rake Sarasin.

Muhammad, 2000, Sistem dan Prosedur Operasional Bank Syari'ah, Yogyakarta: UII Press.

Mujib, Abdul, et. al, 1994, Kamus Istilah Fiqh, Jakarta: PT Pustaka Firdaus.

Munawir, Ahmad Wanson, 1997, Al Munawir Kamus Arab-Indonesia, Surabaya: Pustaka Progesif.

Nienhaus, Volker, 1989, Epistemology, Methodology and Economic Policy: Some Thought on Mainstream, Austrian and Islamic Economics. Humanomics, 5 (1), 91-111.

Ningsih, Wiwik F., 2015, Modifikasi Pembiayaan Salam dan Implikasi Perlakuan Akuntansi Salam, Jurnal Akuntansi Universitas Jember Vol. 13 No.2 Desember.

Obiyathullah, B., 1999, Derivative Instruments and Islamic Finance, International Journal of Islamic Financial Services, 1, no. 1.

Omar, Emi N., Jaafar, Harlina S., 2011, Halal Supply Chain in the Food Industry : A Conceptual Framework, IEEE Symposium on Business, Engineering and Industrial Application (ISBEIA), Langkawi, Malaysia.

Omar, Mohd. Azmi, M. Abduh, R. Sukmana, 2012, Fundamentals of Islamic Money and Capital Markets, Wiley Finance Series, Singapore.

Otoritas Jasa Keuangan (OJK), 2014, Siaran Pers : Daftar 262 Investasi Bodong, www.ojk.go.id

Petracci, M., Bianchi, M. and Cavani, C., 2010, Pre-slaughter handling and slaughter factors influencing poultry product quality, Vol. 66, No.5. 
Rivai, Harif Amali, 2006, Identifikasi Faktor Penentu Keputusan Konsumen Dalam Memilih Jasa Perbankan : Bank Syariah Vs Bank Konvensional, Jurnal Center For Banking Research Universitas Andalas.

Rokhman, Fatkhur, “Manajemen Risiko dalam Islam” artikel diakses pada 23 Maret 2012 dari http:// xa.yimg.com/kq/groups/24017033/470117059/name/Manajemen.

Ryandono, M. N. H., 2009, Bursa Efek dan Investasi Syariah, Serambi, Yogyakarta, Indonesia.

Sabiq, Sayyid, 1998, Fiqh Sunnah jilid 11, Terjemahan Kamaludin A Marzuki, Bandung: Pustaka.

Seelajaroen, R., 2000, Hedge Ratios and Hedging Effectiveness of the SPI Futures Contract, Working Paper Series in Finance, vol.00-09.

Shihab, M. Q., 2002, Tafsir Al Misbah, Lentera Hati, Jakarta, Indonesia.

Shihab, M. Quraisy, Tafsir Al-Mishbah, (Jakarta: Lentera Hati, 2002), Cet. Ke-V.

Siddiqi, Muhammad Nejatullah, 1981, Restructuring the study of economics in Muslim universities. In Isma'il R. Al-Faruqi and Abdullah Omar Nasseef (eds.), Social and natural sciences: The Islamic perspective (pp. 71-86). Jeddah: King Abdulaziz University.

Siddiqi, Muhammad Nejatullah, 2001, Economics : An Islamic approach. Islamabad : Institute Policy Studies and The Islamic Foundation.

Sudarsono, Heri 2003, Bank dan Lembaga Keuangan Syari'ah, Yogyakarta: Ekonsia.

Suhendi, Hendi, 2002, Fiqh Muamalah, Jakarta: PT Raja Grafindo.

Sutedi, Adrian, 2012, Produk-Produk Derivatif dan Aspek Hukumnya, Penerbit Alfabeta, Bandung.

Suwailem, S., 2006, Hedging in Islamic Finance, Islamic Development Bank, Occasional Paper No. 10.

Talib, Z., Zailani, S. and Zainuddin, Y., 2010, Conceptualization on the Dimensions for Halal Orientation for Foods Manufacturers: A Study in the Context of Malaysia, Pakistan Journal of Social Sciences. Vol. 7 No. 2, pp 56-6.

Tim Pengembangan Perbankan Syari'ah Institut Bankir Indonesia, 2001, Konsep, Produk dan Implementasi Operasional,Jakarta : Djambatun.

Triyuwono, Iwan, 2015, Akuntansi Syariah : Perspektif, Metodologi, dan Teori, Edisi Kedua, Cetakan Keempat, Rajawali Pers, Jakarta.

Umar, Husein, 2001, Manajemen Resiko Bisnis : Pendekatan Analisis Finansial dan Non-Finansial, Gramedia Pustaka Utama, Jakarta, Indonesia.

Umar, M. Abdul Halim, 1995, Shari'ah, Economic and Accounting Framework of Bay Al Salam in the Light of Contemporary Application, Research Paper No. 33, Islamic Research and Training Institute, Islamic Development Bank, Jeddah, Saudi Arabia.

Zahan, M., \& Kenett, R. S., 2012, Hedging instruments in conventional and Islamic finance. Journal of 
Applied Statistical Analysis: Decision Support Systems and Services Evalation EJASA: DSS, $3(1), 59-74$.

Zailani, Suhaiza et al, 2009, Halal Traceability and Halal Tracking Systems in Strengthening Halal Food Supply Chain for Food Industry in Malaysia, $18^{\text {th }}$ International Conference Society for Global Business \& Economic Development, Bratislava, Slovak Republic, May 27-30.

Zarqa, Muhammmad Anas, 1987, Problem of research in the theory of Islamic economics and suggested solutions. In Problem of research in Islamic economics (pp. 52-63). Jordan: The Royal Academy for Islamic Civilization Research.

Zarqa, Muhammmad Anas, 2003, Islamization of economics: The concept and methodology. Journal of King Abdul Azis University: Islamic Economics, 16 (1), 3-42. 